\title{
Molecular events involved in the increased expression of matrix metalloproteinase- 9 by $T$ lymphocytes of mammary tumor-bearing mice
}

\author{
JENNIFER L. OWEN ${ }^{1}$, MARTA TORROELLA-KOURI ${ }^{2,3}$ and VIJAYA IRAGAVARAPU-CHARYULU ${ }^{1,3}$ \\ ${ }^{1}$ Department of Biomedical Sciences, Florida Atlantic University, Boca Raton, FL 33431; \\ ${ }^{2}$ Department of Microbiology and Immunology, University of Miami Miller School of Medicine, \\ Miami, FL 33136; ${ }^{3}$ The Sylvester Cancer Center, Miami, FL 33136, USA
}

Received September 10, 2007; Accepted October 22, 2007

\begin{abstract}
Matrix metalloproteinases (MMPs) are a family of extracellular proteinases whose contributions to cancer progression have been studied because of their matrixdegrading abilities and elevated expression in advanced stage tumors. Recent findings suggest a role for MMPs during the multiple stages of tumor progression including establishment and growth, migration, invasion, metastasis, and angiogenesis. MMP-9 regulation at the molecular level can be studied by measuring the effect(s) of a variety of physiological and pharmacological agents on cells. Multiple signaling molecules such as protein kinase $\mathrm{C}$, pertussis toxin-sensitive guanine nucleotide-binding protein $\mathrm{G}$, and protein tyrosine kinases are known to mediate the secretion of MMPs in cell lines. We previously reported an upregulation of MMP-9 in T cells of mammary tumor-bearing mice. In this study, pharmacologic inhibitors were used to dissect the signaling pathways involved in the upregulation of MMP-9 in the splenic T cells of normal and mammary tumor-bearing mice. Staurosporine, a protein kinase inhibitor, stimulated MMP-9 secretion by normal T lymphocytes, while the constitutively high levels of MMP-9 produced by tumor bearers' T cells were decreased by Genistein, a specific tyrosine kinase inhibitor, and Rottlerin, a PKC inhibitor. Using a NF- $\kappa \mathrm{B}$ specific probe to the murine MMP-9 promoter, electromobility shift assays of nuclear proteins from normal and tumor bearers' splenic $\mathrm{T}$ cells revealed a pattern of higher intensity bands from the tumor bearers' nuclear extracts, indicating a greater amount of these transcription factors bound to the recognition motif. When mammary tumor bearers' $\mathrm{T}$ cells were cultured with the NF- $\kappa \mathrm{B}$ inhibitors, N-p-Tosyl- ${ }_{\mathrm{L}}$-lysine chloromethyl ketone
\end{abstract}

Correspondence to: Dr Vijaya Iragavarapu-Charyulu, Florida Atlantic University, 777 Glades Road, Boca Raton, FL 33431, USA E-mail:iragavar@fau.edu

Key words: matrix metalloproteinase-9, T lymphocytes, mammary tumor, signaling hydrochloride and Bay 11-7082, there was a subsequent decreased production of MMP-9. These results suggest that the tumor burden may be activating various signaling pathways within splenic T lymphocytes to upregulate MMP-9 expression.

\section{Introduction}

Matrix metalloproteinases (MMPs) are a family of extracellular matrix (ECM)-degrading proteinases whose contributions to cancer progression have been studied because of their matrix-degrading abilities and elevated expression in advanced stage tumors. Recent findings suggest a role for MMPs during the multiple stages of tumor progression including establishment and growth, angiogenesis, as well as migration (1). MMPs exert these effects by cleaving many different substrates, which include not only structural components of the ECM, but also growth factor binding proteins, growth factor precursors, receptor tyrosine kinases, cell-adhesion molecules and other proteinases. Sheu et al have suggested an additional role for MMPs in cancermediated immunosuppression by demonstrating that tumorderived MMP-9 induces the proteolytic cleavage of IL-2R $\alpha$ on activated $\mathrm{T}$ cells and downregulates the proliferative capability of cancer-encountered T cells (2). Thus, MMPs can regulate the tumor microenvironment, and their expression and activation are increased in almost all human cancers compared with normal tissue (3).

In animal models, macrophages, neutrophils, and mast cells are contributors to the progression of cancer. Inflammatory cells secrete several MMPs, including -9, -12, and -14, and can promote cancer progression by releasing these proteases (4). Indeed, Coussens et al have shown that MMP-9 derived from inflammatory cells of squamous carcinomas can serve the neoplasm by promoting angiogenesis, neoplastic cell proliferation, and progression to malignant cancer, suggesting a role for the inflammatory cells as co-conspirators in carcinogenesis (5). Greater understanding of the mechanisms by which MMP expression or activity is regulated is vital because of the potential therapeutic applications of controlling such processes, as well as enhancing our knowledge of the mechanisms associated with tumor progression and metastasis (6). In fact, taking advantage of increased MMP activity in 
tumors, recombinant proteins containing anthrax toxin fused to an MMP cleavage site have been developed. These recombinant toxin proteins are activated by MMP cleavage at the cell surface and are internalized by the tumor, leading to cell death (7).

Previous studies in our laboratory have demonstrated that the growth of the D1-DMBA-3 mammary tumor causes multiple alterations in the $\mathrm{T}$ lymphocyte population. We showed that there is a progressive loss of delayed-type hypersensitivity (8), as well as a decrease in the proliferative responses to mitogens and tumor-associated antigens (9), and a downregulation of IFN- $\gamma$ in tumor bearers' T cells (10). Splenic T lymphocytes from mammary tumor bearers also show an upregulation of CCL2 (11) and MMP-9 in comparison to $\mathrm{T}$ cells from normal animals (12). Furthermore, we previously reported that inflammatory cells, specifically the T lymphocytes, are the key contributors of MMP-9 in the tumor microenvironment (12). The production and secretion of these proteinases by $\mathrm{T}$ cells could have deleterious consequences for the host if enhanced tumor and capillary growth result. In the present study we identified the molecular events leading to the elevated secretion of MMP-9 by $\mathrm{T}$ lymphocytes of mammary tumor-bearing mice.

\section{Materials and methods}

Mice and cell lines. BALB/c mice used in these studies were 8-12 weeks of age and were bred in our animal facility at the University of Miami. Animal care and use complied with the guidelines of the National Institutes of Health. The D1DMBA-3 tumor, syngeneic to BALB/c mice, is a transplantable mammary adenocarcinoma derived from a nonviral, noncarcinogen-induced preneoplastic nodule after treatment with 7,12-dimethylbenzanthracene (13). The D1DMBA-3 tumor is immunogenic to the host of origin, nonmetastatic to the spleen, but metastases to the lung and bone marrow occur. The DA-3 mammary tumor cell line was derived from the D1-DMBA-3 tumor and maintained in DMEM/high glucose, $10 \%$ characterized heat-inactivated FCS (Hyclone Laboratories, Logan, UT), $100 \mathrm{U} / \mathrm{ml}$ of penicillin, $100 \mu \mathrm{g} / \mathrm{ml}$ of streptomycin, and OPI media supplement (Sigma Chemical Co., St. Louis, MO). Tumors were implanted in BALB/c mice by subcutaneous injection of $1 \times 10^{6}$ tumor cells resulting in a measurable tumor 7-10 days post implantation.

Purification of splenic $T$ cells. Spleens were compressed in Teflon tissue homogenizers and the resulting single-cell suspension was pelleted at $300 \mathrm{x} \mathrm{g}$, subjected to hypotonic shock for red cell removal, washed and counted. Macrophages were removed from the cell suspension by plastic adherence in pre-warmed RPMI-1640, 5\% FCS at $37^{\circ} \mathrm{C}$ for $1 \mathrm{~h}$ in a $\mathrm{CO}_{2}$ incubator. The non-adherent $\mathrm{T}$ lymphocytes were purified on nylon wool columns according to the method of Julius et al (14) and by positive selection using the MACS magnetic separation system (Miltenyi Biotec, Auburn, CA) according to the manufacturer's instructions. Briefly, single-cell suspensions in cold PEB buffer (PBS supplemented with $2 \mathrm{mM}$ EDTA and $0.5 \%$ BSA) were incubated with supermagnetic microbeads conjugated to anti-mouse CD90 (Thy1.2) at $4{ }^{\circ} \mathrm{C}$ for $15 \mathrm{~min}$. Cells were washed twice and loaded onto the magnetic separation columns. The columns were washed three times with cold PEB buffer, and the positively selected Thy $1.2^{+}$cells were then eluted. After purification, the cells were routinely $>95 \%$ viable, as assessed by trypan blue exclusion. FACS analysis using a Becton Dickinson LSR analyzer and anti-mouse FITC-CD90 (BD Biosciences Pharmingen, San Diego, CA) confirmed the populations to be $\geq 93 \%$ Thy $1.2^{+}$lymphocytes.

Cell culture. After purification, splenic T cells were cultured at $2 \times 10^{6}$ cells $/ \mathrm{ml}$ in complete media consisting of RPMI$1640,10 \% \mathrm{FCS}, 100 \mathrm{U} / \mathrm{ml}$ penicillin, $100 \mu \mathrm{g} / \mathrm{ml}$ of streptomycin, and $50 \mathrm{mM} 2-\mathrm{ME}$ for varied time periods. For RNA expression and stability studies, the lymphocytes were cultured for $4 \mathrm{~h}$. For cell signaling studies, the $\mathrm{T}$ lymphocytes were cultured for $0,15,45$ and 60 min after the addition of PMA (Sigma-Aldrich, St. Louis, MO) and one of the following inhibitors: TLCK, Bay 11-7082, Genistein, Gö 6976, Rottlerin, or Staurosporine (Calbiochem, San Diego, CA). To determine MMP-9 activity by zymography, purified splenic T cells were first washed 3 times with RPMI-1640 to remove all residual serum before overnight culture $\left(2 \times 10^{6}\right.$ cells $\left./ \mathrm{ml}\right)$ in DMEM/ F12 medium with $100 \mathrm{U} / \mathrm{ml}$ of penicillin, $100 \mu \mathrm{g} / \mathrm{ml}$ of streptomycin, $1 \mathrm{mM}$ L-glutamine, $1 \mathrm{mM}$ sodium pyruvate, and $1 \mathrm{X}$ non-essential amino acids (all from Life Technologies, Grand Island, NY). At the end of the incubation period, the supernatants were removed and stored at $-80^{\circ} \mathrm{C}$.

RNA analyses. Standard Northern blot technique was followed using the Northern Max ${ }^{\mathrm{TM}}$ formaldehyde-based system (Ambion, Austin, TX). Briefly, total RNA (10 $\mu \mathrm{g})$ was electrophoresed through agarose-formaldehyde gels, blotted onto nylon membranes by capillary electrophoresis, followed by prehybridization of the membrane, and hybridization with the appropriate radiolabeled probe. Blots were pre-incubated in the ULTRAhyb ${ }^{\mathrm{TM}}$ hybridization solution for $3 \mathrm{~h}$ at $42^{\circ} \mathrm{C}$ and then hybridized at $42^{\circ} \mathrm{C}$ overnight in ULTRAhyb with an $\left[\alpha^{-}{ }^{32} \mathrm{P}\right] \mathrm{dATP}-$ radiolabeled DNA probe. Probes were prepared by random priming either $\beta$-actin or MMP- 9 cDNA (Decaprime II kit; Ambion). Blots were exposed to Kodak autoradiography film (Kodak, Rochester, NY) overnight.

RNA stability studies were performed by culturing splenic $\mathrm{T}$ lymphocytes from normal and 3-week tumor-bearing mice for $2 \mathrm{~h}$. Actinomycin $\mathrm{D}(50 \mu \mathrm{g} / \mathrm{ml})$ was then added to inhibit further transcription, and RNA was extracted at 30-min intervals for up to $4 \mathrm{~h}$. Northern hybridization was performed as described above.

Nuclear extracts. Nuclear extracts were prepared by the method of Schreiber et al (15). T cells were cultured overnight, washed twice with PBS and then treated with cold buffer A (10 mM HEPES, pH 7.9, $10 \mathrm{mM} \mathrm{KCl,} 0.1 \mathrm{mM}$ EDTA, $0.1 \mathrm{mM}$ EGTA, $1 \mathrm{mM}$ DTT, $0.5 \mathrm{mM}$ PMSF, $0.1 \mathrm{mM}$ antipain, $10 \mathrm{mg} /$ $\mathrm{ml}$ aprotinin, $0.1 \mathrm{mM}$ chymostatin, $0.1 \mathrm{mM}$ leupeptin, and $1 \mathrm{mM}$ pepstatin). The cells were allowed to swell on ice for 15 min, after which $25 \mu 1$ of $10 \%$ NP-40 was added and vortexed for $10 \mathrm{sec}$. Nuclei were removed from the cytosol by centrifugation at $14,000 \mathrm{rpm}$ for $30 \mathrm{sec}$. The supernatants were removed and the nuclear pellets re-suspended in $50 \mu 1$ 
ice cold buffer B (20 mM HEPES, pH 7.9, 0.4 M NaCl, $1 \mathrm{mM}$ EDTA, $1 \mathrm{mM}$ DTT, $1 \mathrm{mM}$ PMSF, $0.1 \mathrm{mM}$ antipain, $10 \mu \mathrm{g} /$ $\mathrm{ml}$ aprotinin, $0.1 \mathrm{mM}$ chymostatin, $0.1 \mathrm{mM}$ leupeptin, and $1 \mathrm{mM}$ pepstatin) and the tubes were rocked vigorously at $4^{\circ} \mathrm{C}$ for $15 \mathrm{~min}$. The extracts were centrifuged at $14,000 \mathrm{rpm}$ for 5 min at $4^{\circ} \mathrm{C}$, and the supernatants stored at $-70^{\circ} \mathrm{C}$. Protein concentration was measured by a previously described modification of the method of Lowry et al [Peterson (16)] using the Sigma protein determination kit.

Electrophoretic mobility shift assay (EMSA). Nuclear extracts $(5 \mu \mathrm{g} / \mathrm{sample})$ were incubated in a $20-\mu 1$ volume with $1 \mathrm{X}$ binding buffer $(10 \mathrm{mM}$ Tris- $\mathrm{HCl}, \mathrm{pH} 7.5,50 \mathrm{mM}$ $\mathrm{NaCl}$, and $0.5 \mathrm{mM}$ DTT), $10 \%$ glycerol, $0.05 \% \mathrm{NP}-40,1 \mu \mathrm{g}$ of poly(dI-dC)-poly(dI-dC) (Pharmacia, Piscataway, NJ) on ice for $10 \mathrm{~min}$ (17) before addition of ${ }^{32} \mathrm{P}$-labeled target DNA (1 ng), corresponding to sequences in the promoter to be analyzed. To ensure specificity, a 50X concentration (50 ng) of unlabeled competitor DNA was included in the sample prior to the addition of the radiolabeled probe. After the completion of the binding reaction, $2 \mu \mathrm{l}$ of $10 \mathrm{X}$ loading buffer (250 mM Tris-HCl, pH 7.5, 0.2\% bromophenol blue, $0.2 \%$ xylene cyanol, and $40 \%$ glycerol) was added and samples were electrophoresed at $4{ }^{\circ} \mathrm{C}$ through a $5 \%$ polyacrylamide gel in $0.5 \mathrm{X}$ TBE buffer $(0.045 \mathrm{M}$ Tris-borate, $0.001 \mathrm{M}$ EDTA, pH 8.0) which had been pre-run at $10 \mathrm{~V} / \mathrm{cm}$ for $2 \mathrm{~h}$ prior to the sample loading. The gels were dried and visualized by autoradiography.

Supershift assay. In some of the EMSAs, the procedure was followed as detailed above except that $2 \mu \mathrm{g}$ of affinity-purified rabbit polyclonal antibodies against various transcription factors (Santa Cruz Biotechnology, Santa Cruz, CA) were included in the binding reaction. Antibodies were blocked by the addition of excess specific peptides.

Zymography. Gelatin zymography followed a modified procedure of Heussen and Dowdle (18) for detecting picogram amounts of MMP-2 and -9. Identical amounts of supernatant were electrophoresed under non-reducing conditions using $10 \%$ SDS-polyacrylamide gels containing $0.33 \mathrm{mg} / \mathrm{ml}$ gelatin. After electrophoresis, the gels were washed twice in $2.5 \%$ Triton X-100 for 15 min to remove SDS. Following overnight incubation at $37^{\circ} \mathrm{C}$ in assay/incubation buffer $(50 \mathrm{mM}$ Tris$\mathrm{HCl}, \mathrm{pH} 7.5,200 \mathrm{mM} \mathrm{NaCl}, 1 \mu \mathrm{M} \mathrm{ZnCl}_{2}, 0.02 \% \mathrm{NaN}_{3}$ and $0.005 \%$ Brij 35), the gels were stained for $2 \mathrm{~h}$ with Coomassie blue R 250 and destained with 7\% acetic acid. Both latent and active forms of gelatinases produce clear areas in the gel.

Western blot analysis. T lymphocytes were cultured for 0 , 15,45 and $60 \mathrm{~min}$ in complete media, stimulated with $10 \mathrm{ng} /$ ml PMA (Sigma-Aldrich) in the presence or absence of a titrating concentration of inhibitors of signal transduction pathways including TLCK, Bay 11-7082, Staurosporine, Genistein, Gö 6975 and Rottlerin. Whole cell lysates were isolated as previously described (19). Protein concentration was normalized by comparison with BSA standards (Sigma Chemical). The proteins were resolved on $10 \%$ SDS polyacrylamide gels under reducing conditions and then transferred onto Protran nitrocellulose membranes $(0.45-\mu \mathrm{m}$ pore size; Schleicher \& Schuell Inc., Keene, NH) using a Trans-Blot electrophoretic cell (Bio-Rad, Hercules, CA). Membranes were blocked for $1 \mathrm{~h}$ at room temperature in 5\% nonfat dry milk in $1 \mathrm{X}$ TBS- $0.1 \%$ Tween-20 followed by a 1-h incubation at room temperature with the following primary antibodies: rabbit anti-IкB- $\alpha$, anti-IкB- $\beta$, anti-IкB- $\varepsilon$, IKK- $\alpha$, IKK- $\gamma$, anti-phosphotyrosine, anti-PKC $\alpha$, anti-PKC $\beta$, anti$\mathrm{PKC} \delta$ and anti-PKCE (all from Santa Cruz Biotechnology). Blots were washed for 30 min with five changes of $1 \mathrm{X}$ TBS$0.1 \%$ Tween-20 solution followed by a $1-\mathrm{h}$ incubation at room temperature with the HRP-conjugated anti-rabbit IgG $\mathrm{Ab}$ (Chemicon International). Blots were washed again for $30 \mathrm{~min}$ and incubated for $3 \mathrm{~min}$ with Supersignal West Pico chemiluminescent substrate (Pierce, Rockford, IL). The results were visualized by exposing blots to Kodak autoradiographic film.

\section{Results}

Increased MMP-9 mRNA expression in T lymphocytes of tumor-bearing mice. To determine whether the increased levels of MMP-9 secretion in the T cells from mammary tumor-bearers were due to altered transcription, MMP-9 gene expression in normal and tumor-bearing mice was analyzed by Northern blotting using a murine-specific cDNA probe. In Fig. 1A, the level of MMP-9 mRNA was barely detectable in $\mathrm{T}$ cells from normal mice. Splenic T cells from mice bearing 3 -week tumors had higher levels of each of the two different murine MMP-9 mRNAs (2.5 and $3.2 \mathrm{~kb}$ ), in comparison to T cells from normal mice. The equivalence of RNA loading in different lanes was ascertained by rehybridization to a $\beta$-actin probe. Further studies were performed to determine whether increased MMP-9 expression resulted from increased de novo mRNA synthesis, decreased mRNA decay rates, or both. No difference in MMP-9 mRNA stability was detected by Northern blotting of total RNA from normal and tumor bearers' $\mathrm{T}$ cells cultured for $4 \mathrm{~h}$ after the addition of $50 \mu \mathrm{g} / \mathrm{ml}$ of actinomycin D (Fig. 1B), suggesting that increased MMP-9 mRNA resulted from de novo synthesis.

Murine MMP-9 promoter analysis. Promoter analysis of MMP-9 has been performed in osteoclasts and keratinocytes (20) and in WEHI-3 macrophages (21). Reports on the roles of AP-1 and NF-кB in the upregulation of MMP-9 in human foreskin fibroblasts and rabbit dermal fibroblasts (22) and of the participation of $\mathrm{NF}-\kappa \mathrm{B}, \mathrm{Sp} 1$, Ets, AP-1 and a retinoblastoma binding element in the transcriptional regulation of MMP-9 expression in an H-ras- and v-myc-transformed rat embryo cell line (23) have provided some background on which to base the selection of the promoter probes and antibodies for use in the electromobility shift assays (EMSA) and supershift assays.

In Fig. 2, all lanes were loaded with $5 \mu \mathrm{g}$ of nuclear protein extracts from 2-h cultures of splenic T cells and probed with a specific probe corresponding to the $N F-\kappa B$ site in the murine MMP-9 promoter. Electromobility shift assays (EMSA) indicated that the probed nuclear proteins from the tumor bearers' $\mathrm{T}$ cells migrated faster in the gel than those from normal $\mathrm{T}$ cells, signifying a lower molecular weight of the transcription factor complex with tumor burden. The 
A.

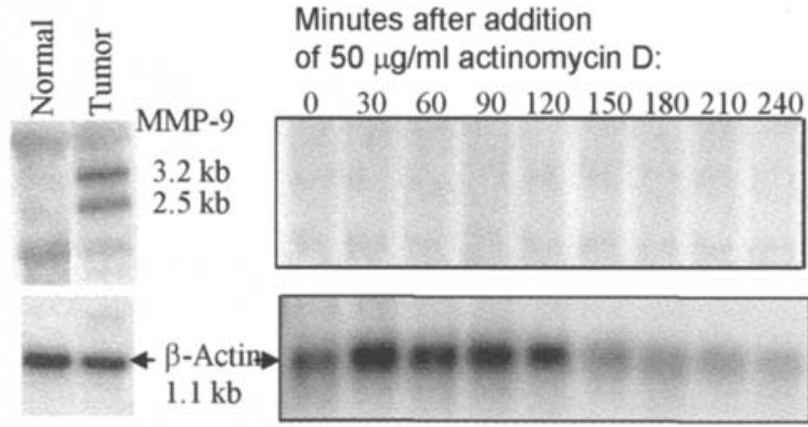

Normal $\begin{array}{lllllllll}0 & 30 & 60 & 90 & 120 & 150 & 180 & 210 & 240\end{array}$
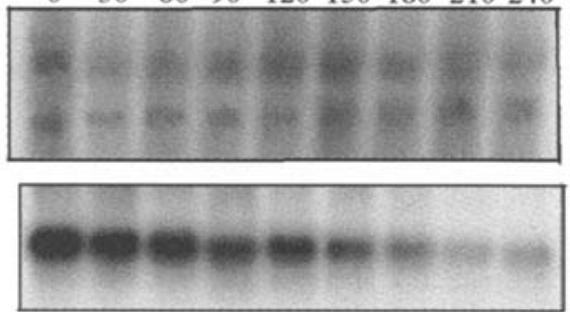

3-Week Tumor

Figure 1. No difference in MMP-9 mRNA stability in T cells from normal and tumor-bearing mice. (A) Splenic T cells from normal and 3-week tumorbearing mice were cultured for $2 \mathrm{~h}$ in serum-free media without stimulation. (B) Actinomycin D ( $50 \mu \mathrm{g} / \mathrm{ml})$ was added to all cultures at time 0 , and total RNA was extracted at 30-min intervals. Northern blots were performed on $10 \mu \mathrm{g}$ RNA using a probe specific for murine MMP-9. The equivalence of RNA loading in different lanes was determined by rehybridization to a $\beta$-actin probe.

A.

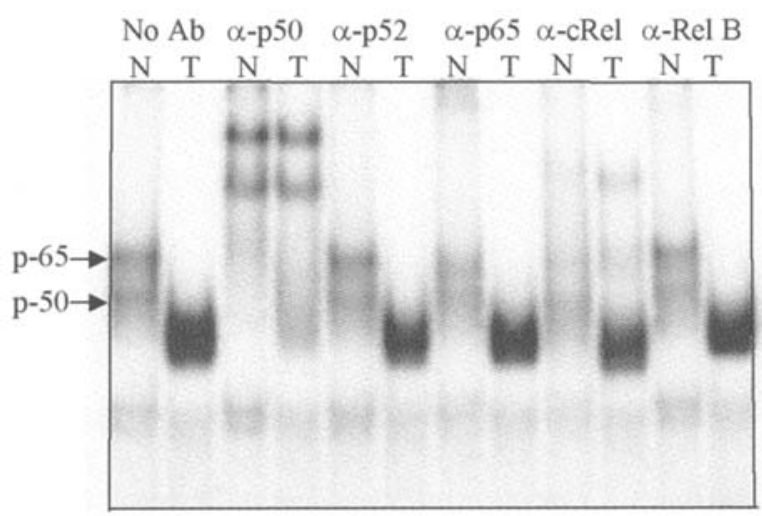

B.

\section{Competition:}

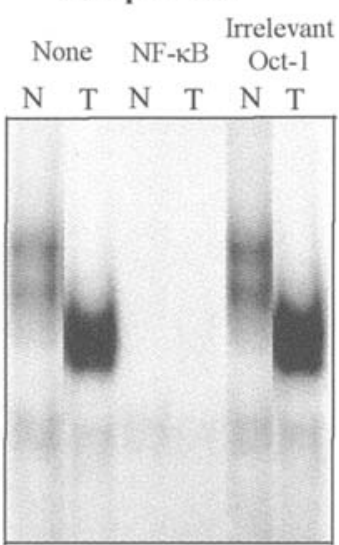

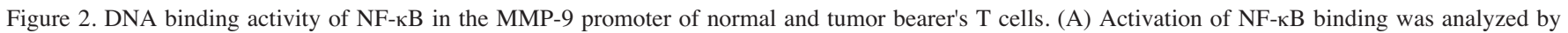
EMSA using a radioactively labeled NF- $\mathrm{B}$ oligonucleotide corresponding to the NF- $\mathrm{B}$ binding site of the murine MMP- 9 promoter. Specific anti-NF- $\mathrm{B}$ transcription factor Abs were included in the binding reactions to determine the complexes bound to the promoter by supershift analysis. (B) The specificity of the DNA-bound complexes was determined by including excess cold competitor as well as an irrelevant cold competition.

resulting bands from the nuclear extracts from tumor bearers' $\mathrm{T}$ cells were of a greater intensity than those of normal $\mathrm{T}$ cells (Fig. 2A, lanes 2 and 1), indicating a greater amount of $\mathrm{NF}-\kappa \mathrm{B}$ transcription factors bound to the recognition motif in the MMP-9 promoter. An EMSA supershift experiment was performed in which antibodies to known NF- $\mathrm{B}$ family members were added to the DNA-binding reaction. Anti-p50, -p65, and -c-Rel antibodies efficiently 'supershifted' the DNA-binding complexes with a concomitant reduction in the intensity of the shifted band, indicating that these transcription factors were involved in the expression of MMP-9 in splenic $\mathrm{T}$ cells (Fig. 2A, lanes 3-4 and 7-10). While p50 was extensively involved in the binding of the NF- $\mathrm{B}$ promoter for both normal and tumor bearers' $\mathrm{T}$ cells, c-Rel played a greater role in the binding of the promoter in normal $\mathrm{T}$ cells, as evidenced by the more dramatic shifts, whereas p65 (RelA) only bound the MMP-9 promoter in normal T cells. The participation of these higher molecular weight transcription factors in the MMP-9 promoter in normal $\mathrm{T}$ cells explains the retarded migration of nuclear extracts compared to those of tumor bearers. The predominant transcription factor complex involved in the NF- $\mathrm{BB}$ promoter in tumor bearer's $\mathrm{T}$ cells is $\mathrm{p} 50 / \mathrm{p} 50$ homodimers. The binding of $\mathrm{p} 50 / \mathrm{p} 50$ homodimers to the NF- $\mathrm{KB}$ binding site was found to enhance collagenase (MMP-1) gene transcription in synovial fibroblasts (24). In this study, we found that the binding of p50/p50 homodimers enhanced MMP-9 gene transcription in $\mathrm{T}$ lymphocytes of mammary tumorbearing mice. The addition of the excess cold competitor eliminated the specific bands but not by an oligonucleotide containing an irrelevant Oct-1 binding motif. This indicates that the bands on the autoradiogram were specific for NF- $\mathrm{kB}$ binding (Fig. 2B).

Since the EMSAs revealed binding of transcription factors to the NF- $\mathrm{KB}$ region of the MMP-9 promoter, studies were performed to confirm that MMP-9 expression was 
A.
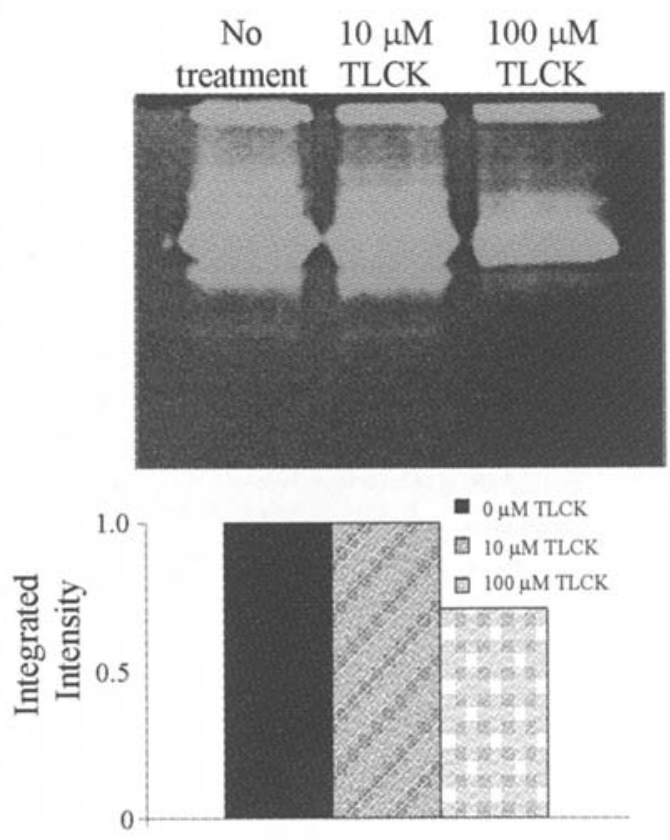

B.

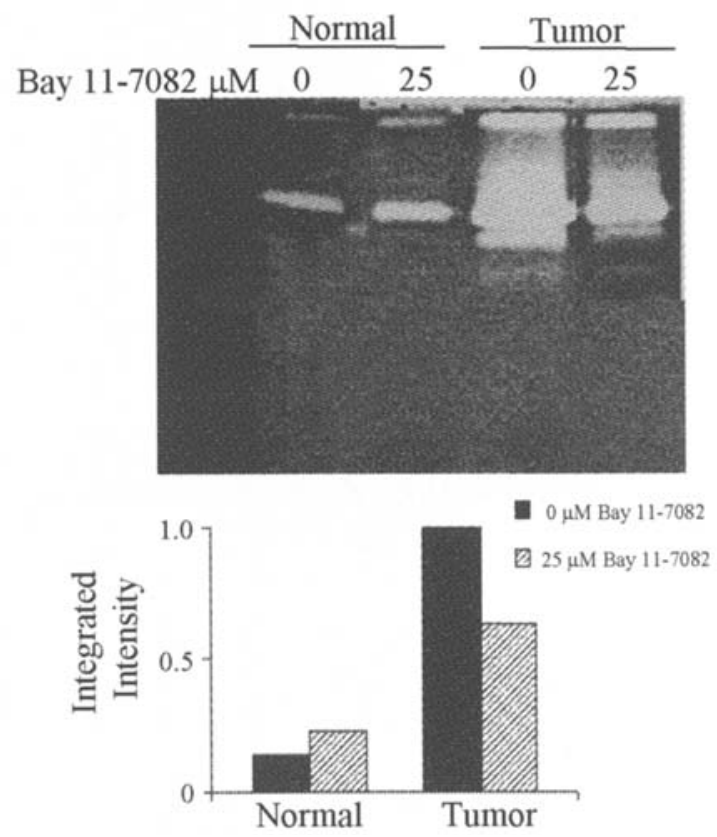

Figure 3. Decreased production of MMP-9 by tumor bearers' T cells cultured with the NF-кB inhibitors, TLCK and Bay 11-7082. Splenic T cells from normal and mice bearing 3-week tumors were purified and cultured overnight with various concentrations of the inhibitor, TLCK $(\mathrm{N} \alpha-\mathrm{p}-\mathrm{Tosyl}$ L-lysine chloromethyl ketone hydrochloride) or Bay 11-7082. Equal amounts of supernatant were assayed by gelatin zymography. (A) MMP-9 secretion was decreased in tumor-bearers' $\mathrm{T}$ cells treated with $100 \mu \mathrm{M}$ TLCK. There was no loss of cell viability, as assayed by trypan blue exclusion. (B) Increased MMP-9 was observed in T cells treated with Bay 11-7082 from normal mice while there was a decrease in MMP-9 production in Bay 11-7082 T cells of mammary tumor-bearing mice.

related to NF-кB activity. Thus, T cells were cultured with different concentrations of TLCK or Bay 11-7082, pharmacologic agents with inhibitory activity towards NF- $\mathrm{kB}$. Treatment of tumor bearers' $\mathrm{T}$ cells with $100 \mu \mathrm{M}$ TLCK resulted in decreased MMP-9 secretion (Fig. 3A). Although TLCK is known to induce apoptotic cell death at concentrations similar to those used in our studies (25), we did not detect any loss of cell viability, as assayed by trypan blue exclusion. In contrast, treatment of $\mathrm{T}$ cells with Bay 11-7082 resulted in a minor increase in MMP-9 secretion by $\mathrm{T}$ cells from normal mice while there was a slight decrease in MMP-9 production in $\mathrm{T}$ lymphocytes of mammary tumor-bearing mice (Fig. 3B).

Assessing the $N F-\kappa B$ signaling events in $T$ cells from normal and tumor-bearing animals. $\mathrm{NF}-\kappa \mathrm{B}$ is a key component necessary for the expression of many proinflammatory cytokines and immunoregulatory molecules. Many studies have established the crucial role of NF- $\mathrm{KB}$ in inflammatory diseases including arthritis, asthma, atherosclerosis, and Alzheimer's disease. The role NF- $\mathrm{BB}$ plays in these diseases probably results from defects in the regulatory mechanisms controlling its activation (26). In most cell types, NF- $\kappa \mathrm{B}$ is sequestered in the cytoplasm in an inactive form through

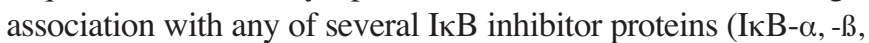
$-\varepsilon,-\gamma, \mathrm{p} 105, \mathrm{p} 100$, and $\mathrm{Bcl}-3)$. In response to a wide array of stimuli, I $\mathrm{B}$ is phosphorylated, ubiquinated, and degraded allowing NF- $\kappa \mathrm{B}$ to translocate to the nucleus where it can regulate gene expression (27). The IкB kinase (IKK) is responsible for the inducible $\mathrm{I} \kappa \mathrm{B}$ phosphorylation at specific amino-terminal serine residues and is the point of convergence for most NF- $\mathrm{KB}$-activating stimuli (28). IKK activity resides in two kinase subunits, IKK- $\alpha$ and IKK- $\beta$, which form homodimers and heterodimers and associate with the regulatory subunit, IKK- $\gamma$. Thus, we determined the expression of IKK- $\alpha$ and the regulatory subunit IKK- $\gamma$ in T cells of normal and tumor-bearing mice. Western blot analysis revealed higher levels of IKK- $\alpha$ and IKK- $\gamma$ in T cells from normal mice but equivalent levels between the two groups were found within 15 min of stimulation with PMA (Fig. 4A). IкB proteins show distinct specificity for the various $N F-\kappa B$ protein dimer combinations. The I $\mathrm{K}$ p proteins specifically interacting with p50/p50 homodimers are p105, Bcl-3, and IкB- $\gamma$. IкB- $\gamma$ preferentially binds to and inhibits p50 homodimers, while IкB- $\alpha$ binds to both p50 homodimers and p50/ p65 heterodimers, but reportedly only inhibits the latter (29). There were higher levels of $\mathrm{NF}-\kappa \mathrm{B}$ transcription factors bound to the recognition motif in the MMP-9 promoter of tumor bearers' $\mathrm{T}$ cells than in normal cells. To examine the role of $\mathrm{I} \kappa \mathrm{B}$ proteins in the sequestration of NF- $\kappa \mathrm{B}$ transcription factors in the $\mathrm{T}$ cells, Western blotting was performed. Western blotting of $50 \mu \mathrm{g}$ whole cell lysates of $\mathrm{T}$ lymphocytes cultured for $60 \mathrm{~min}$ revealed IкB- $\alpha$ in the lysates of normal $\mathrm{T}$ cells, but significantly less in the lysates of tumor bearers' $T$ cells cultured without stimulation (Fig. 4B). In addition, Western blot analysis of splenic $\mathrm{T}$ cells cultured for various time points $(0,15,45,60 \mathrm{~min}$ of culture) revealed more I $\mathrm{KB}-\varepsilon$ in the whole cell lysates of unstimulated normal $\mathrm{T}$ cells compared to those of tumor bearers (Fig. 4C). There was no difference in levels of this protein in stimulated splenic $\mathrm{T}$ cells. IкB- $\varepsilon$ may function primarily in the cytoplasm where it sequesters p65 and c-Rel (30), while IкB- $\alpha$ and IкB- $\beta$ have additional functions that involve entering the nucleus to inhibit Rel DNA binding (27,30-32). 

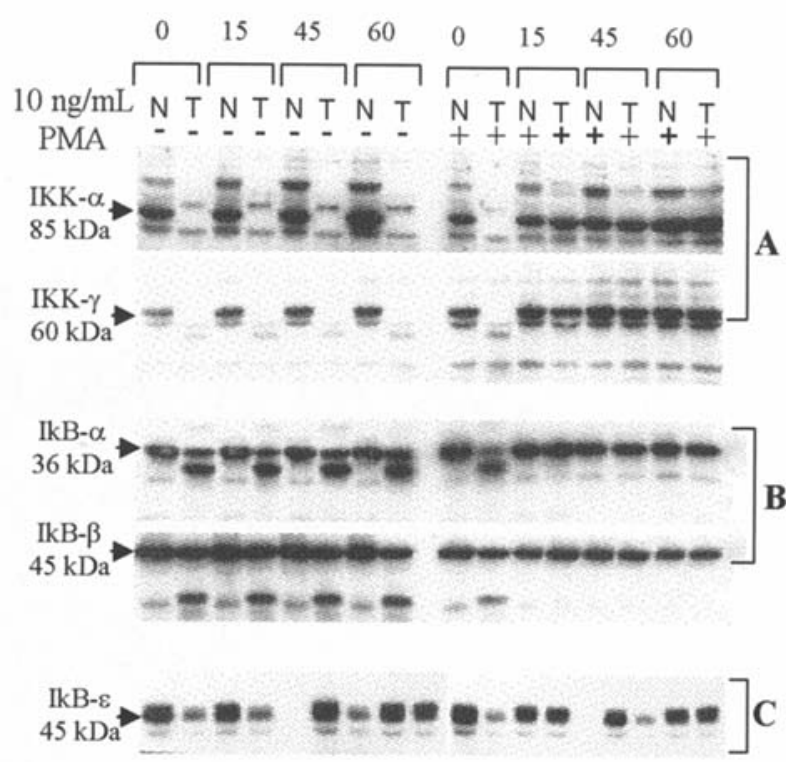

Figure 4. Decreased IKKs and IкB isoforms in the splenic T cells of tumor bearers. Splenic T cells from normal and 3-week tumor-bearing animals were purified and cultured for the various time points with and without PMA stimulation $(10 \mathrm{ng} / \mathrm{ml})$. Whole cell lysates were prepared, and $50 \mu \mathrm{g}$ of protein was subjected to Western blot analysis using antibodies against

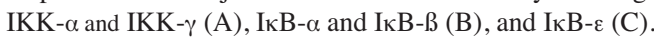

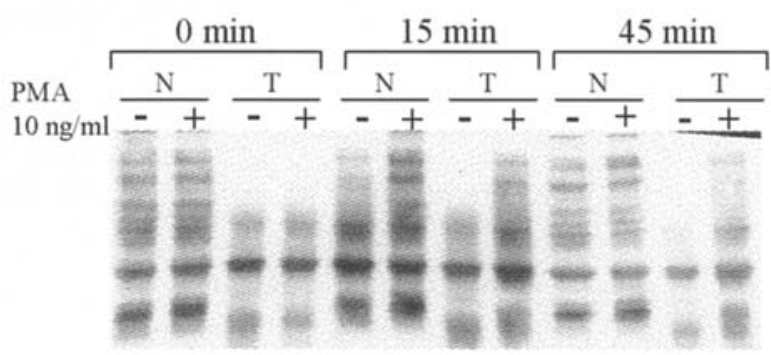

Figure 5. Decreased tyrosine phosphorylation in the splenic T cells of tumor bearers. Splenic T cells from normal and 3-week tumor-bearing animals were purified and cultured for the various time points with and without PMA stimulation $(10 \mathrm{ng} / \mathrm{ml})$. Whole cell lysates were prepared, and $50 \mu \mathrm{g}$ of protein was subjected to Western blot analysis using an antibody against phosphorylated tyrosine.

Assessing the tyrosine kinase and PKC signaling events in $T$ cells from normal and tumor-bearing animals. Because tyrosine kinases and protein kinase $\mathrm{C}$ (PKC) have been considered potent activators of $\mathrm{NF}-\kappa \mathrm{B}$ and $\mathrm{AP}-1$, the contributions of these molecules were explored. In Fig. 5, whole cell lysates from normal and tumor bearers' splenic $\mathrm{T}$ cells were probed with an antibody against phosphorylated tyrosine. Unstimulated tumor bearers' $\mathrm{T}$ cells showed much lower levels of phosphorylated tyrosine throughout the $45 \mathrm{~min}$ of culture suggesting that the upregulation of MMP-9 in tumor bearers' $\mathrm{T}$ cells is either independent of or inhibited by signals transduced by phosphorylated tyrosine. Thus, experiments were performed by treating splenic $\mathrm{T}$ cells treated with different concentrations of Genistein, a specific inhibitor of protein tyrosine kinases. These studies showed decreased MMP-9 secretion in tumor bearers' $\mathrm{T}$ cells with Genistein at the optimal non-toxic concentration dose of $100 \mu \mathrm{M}$ (Fig. 6).
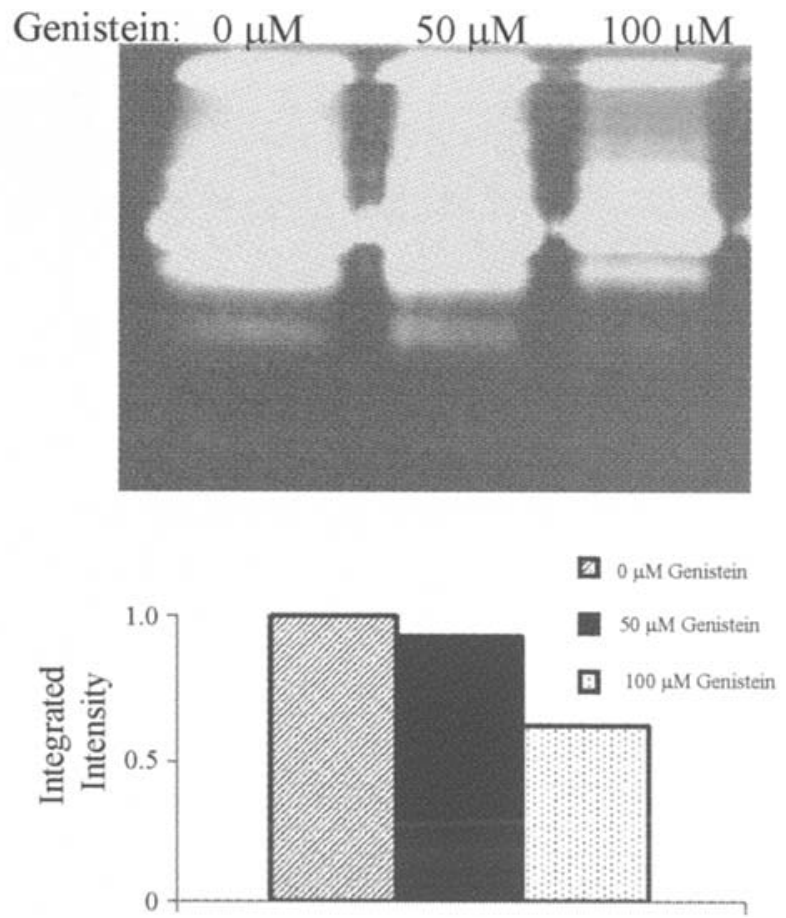

Figure 6. Decreased production of MMP-9 by tumor bearers' T cells cultured with the protein tyrosine kinase inhibitor Genistein. Splenic T cells from mice bearing 3 -week tumors were purified and cultured overnight with various concentrations of Genistein. There was no loss of cell viability, as assayed by trypan blue exclusion. Equal amounts of supernatant were assayed by gelatin zymography.

Protein kinase $\mathrm{C}$ activation by phorbol esters is known to induce MMP-9 expression in a variety of cell types, including $\mathrm{T}$ cells, and phorbol-responsive elements have been characterized in the MMP-9 promoter (33). Nevertheless, $\mathrm{PKC}$ activation is probably not involved in tumor-induced MMP-9 expression in splenic T cells, because stimulation of $\mathrm{T}$ cells with the pleiotropic PKC activator, phorbol myristate acetate (PMA), does not increase the secretion of MMP-9 by normal nor tumor bearers' T cells (12). Yokoo and Kitamura also found that the enhanced MMP-9 expression mediated by IL-1ß in mesangial cells is independent of PKC signaling (34). Upregulation of MMP-9 in murine T lymphocytes may proceed in a $\mathrm{PKC}$-independent manner, or $\mathrm{PKC}$ isoforms may transduce inhibitory signals for the secretion of this proteinase. To assess the expression and function of PKCs in primary splenic T lymphocytes, whole cell lysates were collected of cultured $\mathrm{T}$ cells at various time points with and without PMA stimulation. Using various PKC antibodies, expression of phosphorylation-independent $\mathrm{PKC}$ isoforms was analyzed by Western blotting. We detected increased expression of the conventional or $\mathrm{Ca}^{2+}$-dependent isozymes, PKCs $\alpha$ and $\beta$, and the novel or $\mathrm{Ca}^{2+}-$ independent isozymes, $\varepsilon$ and $\delta$ in normal $\mathrm{T}$ cell lysates compared to those of tumor-bearing animals (Fig. 7). We detected no expression of PKC isoforms $\gamma, \eta, \iota$, or $\lambda$, and detected comparable expression of the receptor for activated $\mathrm{C}$ kinase 1 in the normal and tumor bearers' $\mathrm{T}$ cell lysates (data not shown).

To test the possibility that PKC isoforms may transduce inhibitory signals regarding the expression of MMP-9 in murine $\mathrm{T}$ lymphocytes, we cultured $\mathrm{T}$ cells with different 


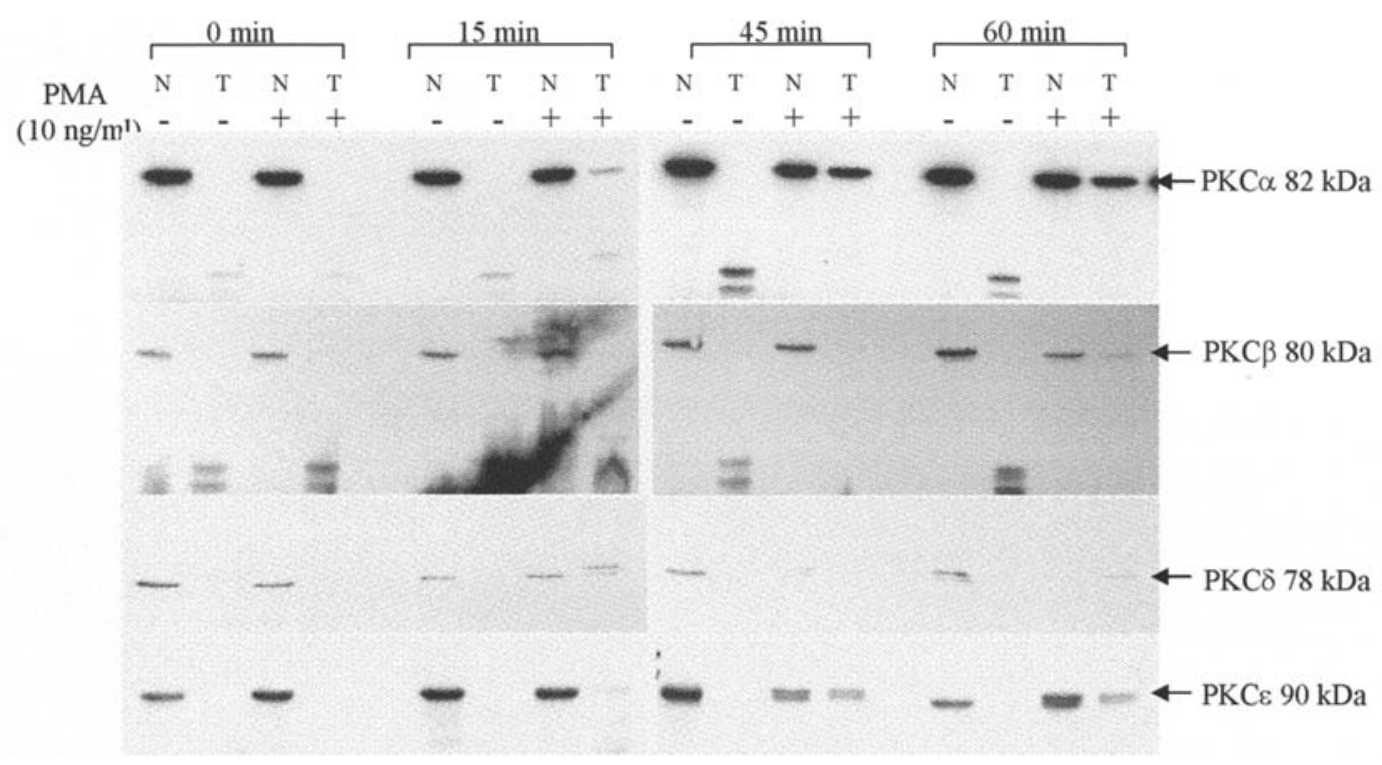

Figure 7. Decreased expression of multiple PKC isoforms in the splenic T cells of tumor bearers. Splenic T cells were purified and cultured for the various time points with and without stimulation (10 ng/ml PMA). Whole cell lysates were prepared and $50 \mu \mathrm{g}$ of protein was subjected to Western blot analysis using antibodies against the PKC isoforms $\alpha, \beta, \delta$, and $\varepsilon$.
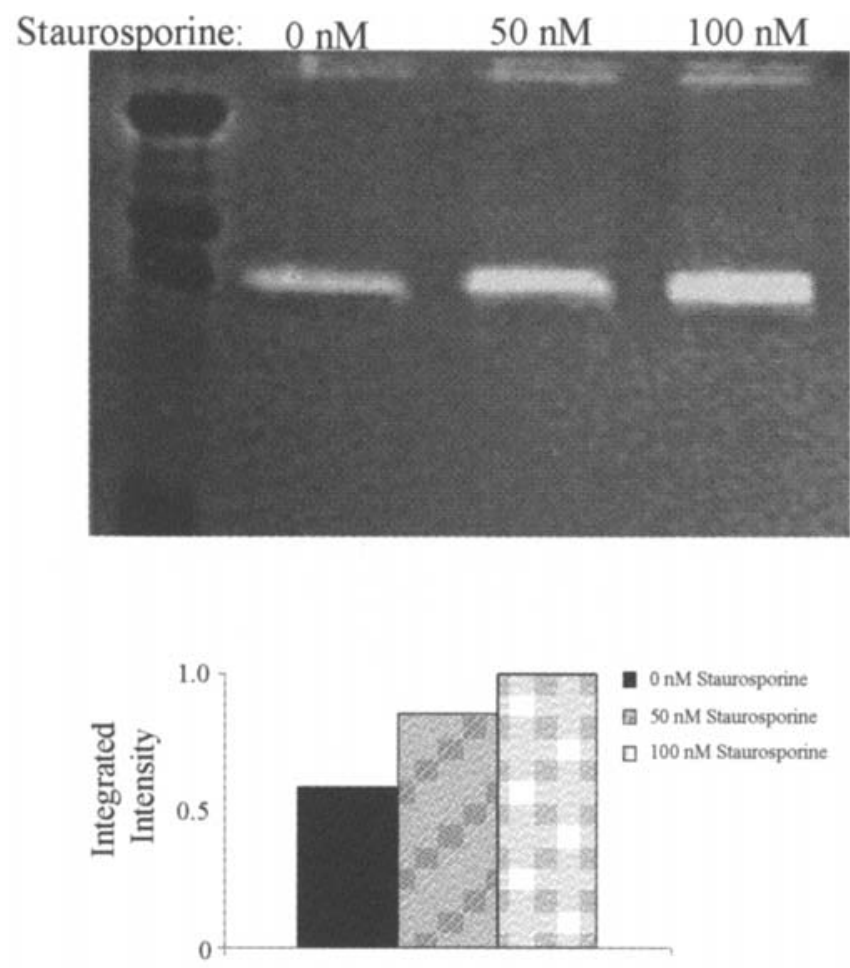

Figure 8. Increased production of MMP-9 by normal T cells cultured with the PKC inhibitor, Staurosporine. Splenic T cells from normal mice were cultured overnight with non-toxic concentrations (confirmed by trypan blue exclusion) of Staurosporine. Equal amounts of supernatants were assayed by gelatin zymography.

concentrations of Staurosporine, a PKC inhibitor. Culturing splenic T cells from normal mice with $50 \mathrm{nM}$ Staurosporine overnight resulted in an increase in MMP-9 secretion (Fig. 8). Pre-treatment of the cells with Genistein, and then culturing with Staurosporine overnight reduced the Staurosporineinduced MMP-9 secretion (data not shown). Aguirre Ghiso et al reported similar results in mammary tumor cell lines (35), suggesting that Staurosporine-induced MMP-9 secretion may be controlled by an endogenous tyrosine kinase pathway, possibly involving protein phosphatases. Thus, normal and tumor bearers' $\mathrm{T}$ cells were treated with Rottlerin, an inhibitor with high specificity towards $\mathrm{Ca}^{2+}$-independent (novel) PKCs ( $\varepsilon$ and $\delta$ ) and Gö 6976 which inhibits $\mathrm{Ca}^{2+}$-dependent (classical) PKCs ( $\alpha$ and $\beta$ ), and we assessed the effects, if any, on MMP-9 expression. Treatment of T lymphocytes from tumor-bearing mice with Rottlerin resulted in decreased MMP-9 secretion at a 50- $\mu \mathrm{M}$ concentration (Fig. 9A) while MMP-9 secretion was not appreciably altered when T cells of tumor-bearing mice were treated with Gö 6976 (Fig. 9B).

\section{Discussion}

We previously reported that MMP-9 is upregulated in T lymphocytes of mammary tumor-bearing mice. In the present study, we investigated the signaling pathways leading to the production of MMP-9 in T cells of tumor-bearing mice. MMPs are important in the turnover of the extracellular matrix and in cell migration (36). Because of their role in immune surveillance, $\mathrm{T}$ cell invasion into the tumor mass is critical in host defense against the neoplasm, a function mediated by MMPs. Our previous studies revealed increased MMP-9 expression in tumor bearers' $T$ cells and the infiltration of the tumor microenvironment by $\mathrm{T}$ lymphocytes through a process involving MMP-9 (12). Thus, we investigated whether the increased MMP-9 expression in T cells was due to de novo synthesis or decreased mRNA decay. Since there were no differences in RNA stability between normal and tumor bearers' T lymphocytes, we concluded that de novo synthesis was a contributing factor to the enhanced MMP-9 expression in T lymphocytes of tumor-bearing mice.

Although there are many reports concerning the induction of MMP-9 by inflammatory cytokines (37-39) and the 
A.
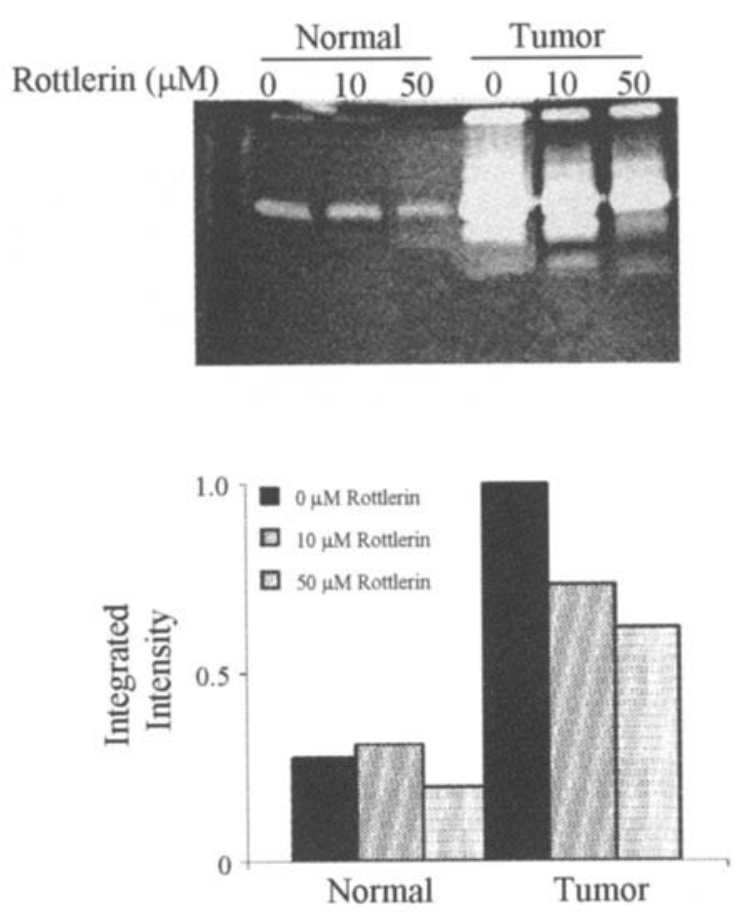

B.
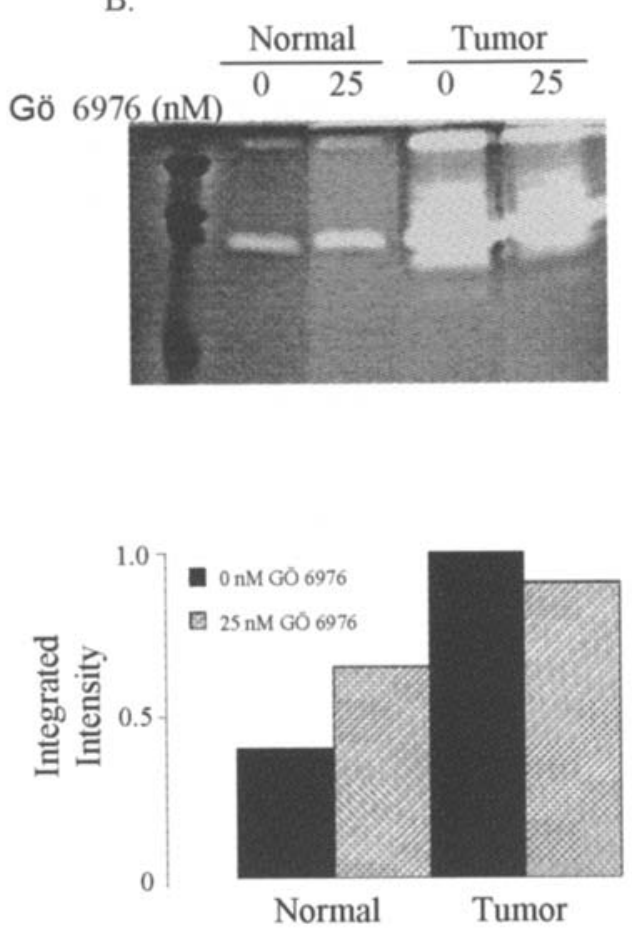

Figure 9. A minor decrease in the production of MMP-9 in the splenic T cells of tumor-bearing mice treated with inhibitors specific for PKC isoforms. Splenic T cells from normal and mice bearing 3-week tumors were purified and cultured overnight with various concentrations of Rottlerin, an inhibitor of $\mathrm{PKC} \delta$ and $\varepsilon$ isoforms (A), and Gö 6976, an inhibitor of $\mathrm{PKC} \alpha$ and $B$ isoforms (B). There was no loss of cell viability, as assayed by trypan blue exclusion. Equal amounts of supernatant were assayed by gelatin zymography.

regulation of this proteinase in tumor cells, less attention has been focused on the signaling events in primary cells. Several studies have reported that the induction of MMP-9 in cell lines stimulated by cytokines involves activation of NF- $\mathrm{KB}$ $(40,41)$. Using nuclear proteins from $\mathrm{T}$ cells from normal and tumor-bearing mice, we performed EMSAs and found increased NF- $\mathrm{BB}$ binding activity to the MMP-9 promoter in tumor bearers' $\mathrm{T}$ cells compared to the normal $\mathrm{T}$ cells. To further confirm the participation of NF- $\mathrm{BB}$ in the induction of MMP-9, T lymphocytes were cultured with inhibitors of NF- $\mathrm{KB}$, and the MMP-9 secretion by the T cells was assessed. Both TLCK and Bay 11-7082 were shown to partially inhibit MMP-9 secretion. NF- $\mathrm{BB}$ is normally sequestered in the cytoplasm of nonstimulated cells, and the subcellular localization of this factor is controlled by inhibitory proteins, IкBs. Exposure of cells to stimuli leads to the rapid phosphorylation, ubiquination and proteolytic degradation of IкB which frees $N F-\kappa B$ to translocate to the nucleus where it regulates gene transcription. Although we did not detect

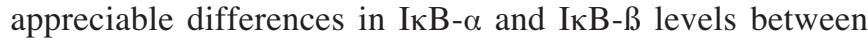
normal and tumor-bearers' $T$ cells unstimulated or stimulated by PMA, we did see higher levels of IкB- $\varepsilon$ in unstimulated T cells of normal mice suggesting that it sequesters p65 and cRel, while IкB- $\alpha$ and IкB- $\beta$ may have additional functions that involve entering the nucleus to inhibit Rel DNA binding. Furthermore, these results imply increased degradation of

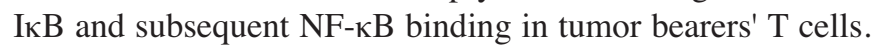
It is possible that $N F-\kappa B$ is regulated differently in tumor bearers' $\mathrm{T}$ cells as there is accumulating evidence that NF- $\mathrm{B}$ is subject to an $\mathrm{I} \kappa \mathrm{B}$-independent level of regulation that involves the phosphorylation of $\mathrm{p} 65$, altering its binding affinities to co-activators and/or repressors (42) or that there are other IкB proteins in the $\mathrm{T}$ cells of normal mice that negatively regulate $\mathrm{NF}-\kappa \mathrm{B}$ in the nucleus.

$\mathrm{NF}-\kappa \mathrm{B}$ can be activated by several different upstream signaling cascades including the $\mathrm{PKC}$, protein tyrosine kinase and p38 MAPK pathways (43-50), depending on the cell type and the stimulus (51-55). Thus, the induction of the MMP-9 gene by signaling pathways upstream of $N F-\kappa B$ was investigated. Since tyrosine kinases are known to be potent activators of NF- $\mathrm{KB}$, the contributions of these protein kinases were explored using whole cell lysates from normal and tumor bearers' splenic T cells and probed with an antibody against phosphorylated tyrosine. Unstimulated tumor bearers' $\mathrm{T}$ cells showed much lower levels of phosphorylated tyrosine compared to the normal cells suggesting that the upregulation of MMP-9 in tumor bearers' $\mathrm{T}$ cells is either independent of or inhibited by signals transduced by phosphorylated tyrosine. Kim et al have shown that Genistein, a tyrosine kinase inhibitor, downregulates the expression of MMPs in rat NK cells (56). We obtained similar findings of decreased MMP-9 secretion when splenic T cells were treated with Genistein. These results suggest that MMP-9 secretion is independent of the tyrosine kinase pathway.

Signaling via PKC in response to growth factors is known to be important for the transcriptional regulation of MMP genes (57). PKC activation by phorbol esters is known to induce MMP-9 in different cell types. However, we showed that $\mathrm{T}$ cells from tumor-bearing mice secrete MMP-9 independent of further stimulation with PMA (12). As it is possible that the upregulation of MMP-9 in T cells of tumor bearers may proceed in a $\mathrm{PKC}$-independent manner or that 
different PKC isoforms may transduce inhibitory signals for MMP-9 induction, T cells were cultured with inhibitors of PKC isoforms, and Western blot analysis was performed. Treatment of normal T cells with the PKC inhibitor Staurosporine increased MMP-9 secretion in T lymphocytes as determined by zymography. In contrast, inhibition of $\mathrm{Ca}^{2+}$-dependent and $\mathrm{Ca}^{2+}$-independent isoforms using Gö 6976 and Rottlerin, respectively, resulted in a more significant decrease in MMP-9 secretion in those treated with the $\mathrm{Ca}^{2+}$-independent inhibitor compared to the $\mathrm{Ca}^{2+}$-dependent isoform. These results suggest that $\mathrm{PKC} \varepsilon$ and $\mathrm{PKC} \delta$ activities are involved in the upregulation of MMP-9 in murine T lymphocytes. We showed that induction of MMP-9 in T cells of tumor-bearing mice involved NF- $\kappa \mathrm{B}$ activation and that PKC isoforms may affect MMP-9 production in the $\mathrm{T}$ cells of mammary tumor-bearing mice. Although some studies have demonstrated that MMP-9 gene transcription is positively regulated by MAPKs (58), we did not observe a positive correlation as higher levels of Erk1/2 and MAPK were found in T cells from normal mice suggesting that signals transduced through these molecules inhibit MMP-9 production by T lymphocytes (data not shown).

In this study we demonstrated enhanced NF- $\mathrm{B}$ activity in unstimulated T lymphocytes of tumor-bearing mice. Since pharmacologic inhibition of $N F-\kappa B$ reduces MMP-9 secretion, this implies that NF- $\kappa \mathrm{B}$ is involved in secretion of this protease in tumor bearers' $\mathrm{T}$ lymphocytes. However, the decreased protein expression of upstream signaling molecules observed in $\mathrm{T}$ cells of tumor-bearing mice suggests one of the following possibilities: a) increased proteosomal activity and ubiquination of the targeted protein; b) negative regulation; or c) additional signaling pathways upstream of $\mathrm{NF}-\kappa \mathrm{B}$ activation are involved in the control of MMP-9 secretion by $\mathrm{T}$ cells of tumor-bearing mice. Our previous and present studies demonstrated upregulation of MMP-9 by T cells from both the spleen and the tumor microenvironment at the transcriptional and translational levels. Thus $\mathrm{T}$ cells appear to be key contributors of MMP-9 in mammary tumor bearers. It is well established that MMPs play a pivotal role in tumor progression by degrading connective tissue barriers, by the release of growth factors sequestered in the extracellular matrix and by promoting angiogenesis $(1,3,59,60)$. Because MMP-9 plays a crucial role in tumor cell invasion, metastasis and angiogenesis, understanding the pathways involved could have ramifications for clinical interventions of tumor celland inflammatory cell-derived MMP-9 production.

\section{Acknowledgements}

We are grateful to Dr Diana Lopez for reviewing the manuscript and for her insightful comments. The excellent technical assistance of Mantley Dorsey Jr is gratefully acknowledged. This study was supported by the Florida Breast Cancer Research Foundation.

\section{References}

1. McCawley LJ and Matrisian LM: Matrix metalloproteinases: multifunctional contributors to tumor progression. Mol Med Today 6: 149-156, 2000.

2. Sheu BC, Hsu SM, Ho HN, Lien HC, Huang SC and Lin RH: A novel role of metalloproteinase in cancer-mediated immunosuppression. Cancer Res 61: 237-242, 2001.
3. Egeblad M and Werb Z: New functions for the matrix metalloproteinases in cancer progression. Nat Rev Cancer 2: 161-174, 2002.

4. Coussens LM and Werb Z: Inflammatory cells and cancer: think different! J Exp Med 193: F23-F26, 2001.

5. Coussens LM, Tinkle CL, Hanahan D and Werb Z: MMP-9 supplied by bone marrow-derived cells contributes to skin carcinogenesis. Cell 103: 481-490, 2000.

6. Curran S and Murray GI: Matrix metalloproteinases: molecular aspects of their roles in tumour invasion and metastasis. Eur J Cancer 36: 1621-1630, 2000.

7. Liu S, Netzel-Arnett S, Birkedal-Hansen H and Leppla SH: Tumor cell-selective cytotoxicity of matrix metalloproteinaseactivated anthrax toxin. Cancer Res 60: 6061-6067, 2000.

8. Paul RD, Ghaffar A, Sigel MM, Charyulu V and Lopez DM: Splenic alterations during mammary tumorigenesis: diverse effects on different immune parameters. Anticancer Res 1: $63-69,1981$

9. Sigel MM, Lopez DM and Ortiz-Muniz G: In vitro immune responses to viral and tumor antigens in murine breast cancer. Cancer Res 36: 748-752, 1976.

10. Cheng $\mathrm{X}$ and Lopez DM: $\mathrm{CD} 4^{+}$, but not $\mathrm{CD} 8^{+}, \mathrm{T}$ cells from mammary tumor-bearing mice have a down-regulated production of IFN-gamma: role of phosphatidyl serine. J Immunol 160: 2735-2741, 1998.

11. Owen JL, Lopez DM, Grosso JF, et al: The expression of CCL2 by $\mathrm{T}$ lymphocytes of mammary tumor bearers: role of tumorderived factors. Cell Immunol 235: 122-135, 2005.

12. Owen JL, Iragavarapu-Charyulu V, Gunja-Smith Z, Herbert LM, Grosso JF and Lopez DM: Up-regulation of matrix metalloproteinase-9 in T lymphocytes of mammary tumor bearers: role of vascular endothelial growth factor. J Immunol 171: 4340-4351, 2003.

13. Medina D and DeOme KB: Response of hyperplastic alveolar nodule outgrowth-line D1 to mammary tumor virus, noduleinducing virus, and prolonged hormonal stimulation acting singly and in combination. J Natl Cancer Inst 42: 303-310, 1969.

14. Julius MH, Simpson E and Herzenberg LA: A rapid method for the isolation of functional thymus-derived murine lymphocytes. Eur J Immunol 3: 645-649, 1973.

15. Schreiber E, Matthias P, Muller MM and Schaffner W: Rapid detection of octamer binding proteins with 'mini-extracts', prepared from a small number of cells. Nucleic Acids Res 17: 6419, 1989.

16. Peterson GL: A simplification of the protein assay method of Lowry et al which is more generally applicable. Anal Biochem 83: 346-356, 1977.

17. Ramanujam P, Fogerty S, Heiser W and Jolly J: Fast gel electrophoresis to analyze DNA-protein interactions. Biotechniques 8: 556-563, 1990.

18. Heussen C and Dowdle EB: Electrophoretic analysis of plasminogen activators in polyacrylamide gels containing sodium dodecyl sulfate and copolymerized substrates. Anal Biochem 102: 196-202, 1980.

19. Calderon C, Huang ZH, Gage DA, Sotomayor EM and Lopez DM: Isolation of a nitric oxide inhibitor from mammary tumor cells and its characterization as phosphatidyl serine. J Exp Med 180: 945-958, 1994.

20. Munaut C, Salonurmi T, Kontusaari S, et al: Murine matrix metalloproteinase 9 gene. 5 '-upstream region contains cis-acting elements for expression in osteoclasts and migrating keratinocytes in transgenic mice. J Biol Chem 274: 5588-5596, 1999.

21. Masure S, Nys G, Fiten P, Van Damme J and Opdenakker G: Mouse gelatinase B. cDNA cloning, regulation of expression and glycosylation in WEHI-3 macrophages and gene organisation. Eur J Biochem 218: 129-141, 1993.

22. Bond M, Fabunmi RP, Baker AH and Newby AC: Synergistic upregulation of metalloproteinase- 9 by growth factors and inflammatory cytokines: an absolute requirement for transcription factor NF-kappa B. FEBS Lett 435: 29-34, 1998.

23. Himelstein BP, Lee EJ, Sato H, Seiki M and Muschel RJ: Transcriptional activation of the matrix metalloproteinase-9 gene in an H-ras and v-myc transformed rat embryo cell line. Oncogene 14: 1995-1998, 1997.

24. Vincenti MP, Coon CI and Brinckerhoff CE: Nuclear factor $\mathrm{kappaB} / \mathrm{p} 50$ activates an element in the distal matrix metalloproteinase 1 promoter in interleukin-1beta-stimulated synovial fibroblasts. Arthritis Rheum 41: 1987-1994, 1998. 
25. Murn J, Urleb U and Mlinaric-Rascan I: Internucleosomal DNA cleavage in apoptotic WEHI 231 cells is mediated by a chymotrypsin-like protease. Genes Cells 9: 1103-1111, 2004.

26. Perkins ND: The Rel/NF-kappa B family: friend and foe. Trends Biochem Sci 25: 434-440, 2000.

27. Epinat JC and Gilmore TD: Diverse agents act at multiple levels to inhibit the Rel/NF-kappaB signal transduction pathway. Oncogene 18: 6896-6909, 1999.

28. Karin $M$ and Ben-Neriah Y: Phosphorylation meets ubiquitination: the control of NF-[kappa]B activity. Annu Rev Immunol 18: 621-663, 2000.

29. Bell S, Matthews JR, Jaffray E and Hay RT: I(kappa)B(gamma) inhibits DNA binding of NF-kappaB p50 homodimers by interacting with residues that contact DNA. Mol Cell Biol 16: 6477-6485, 1996.

30. Tam WF and Sen R: IkappaB family members function by different mechanisms. J Biol Chem 276: 7701-7704, 2001.

31. Tam WF, Wang W and Sen R: Cell-specific association and shuttling of IkappaBalpha provides a mechanism for nuclear NF-kappaB in B lymphocytes. Mol Cell Biol 21: 4837-4846, 2001.

32. Rodriguez MS, Thompson J, Hay RT and Dargemont C: Nuclear retention of IkappaBalpha protects it from signalinduced degradation and inhibits nuclear factor kappaB transcriptional activation. J Biol Chem 274: 9108-9115, 1999.

33. Gum R, Lengyel E, Juarez J, et al: Stimulation of 92-kDa gelatinase B promoter activity by ras is mitogen-activated protein kinase kinase 1-independent and requires multiple transcription factor binding sites including closely spaced PEA3/ets and AP-1 sequences. J Biol Chem 271: 10672-10680, 1996.

34. Yokoo T and Kitamura M: Dual regulation of IL-1 betamediated matrix metalloproteinase- 9 expression in mesangial cells by NF-kappa B and AP-1. Am J Physiol 270: F123-F130, 1996.

35. Aguirre Ghiso JA, Farias EF, Alonso DF and Bal de Kier Joffe E: Secretion of urokinase and metalloproteinase- 9 induced by staurosporine is dependent on a tyrosine kinase pathway in mammary tumor cells. Int J Cancer 76: 362-367, 1998.

36. Naito $\mathrm{Y}$ and Yoshikawa T: Role of matrix metalloproteinases in inflammatory bowel disease. Mol Aspects Med 26: 379-390, 2005.

37. Doller A, el Akool S, Muller R, et al: Molecular mechanisms of cyclosporin A inhibition of the cytokine-induced matrix metalloproteinase-9 in glomerular mesangial cells. J Am Soc Nephrol 18: 581-592, 2007.

38. Di Girolamo N, Indoh I, Jackson N, et al: Human mast cellderived gelatinase B (matrix metalloproteinase-9) is regulated by inflammatory cytokines: role in cell migration. J Immunol 177: 2638-2650, 2006.

39. Hu K, Yang J, Tanaka S, Gonias SL, Mars WM and Liu Y: Tissue-type plasminogen activator acts as a cytokine that triggers intracellular signal transduction and induces matrix metalloproteinase-9 gene expression. J Biol Chem 281: 2120-2127, 2006.

40. Jovanovic DV, Martel-Pelletier J, Di Battista JA, et al: Stimulation of 92-kd gelatinase (matrix metalloproteinase 9) production by interleukin-17 in human monocyte/macrophages: a possible role in rheumatoid arthritis. Arthritis Rheum 43: 1134-1144, 2000.

41. Zhou M, Zhang Y, Ardans JA and Wahl LM: Interferon-gamma differentially regulates monocyte matrix metalloproteinase- 1 and -9 through tumor necrosis factor-alpha and caspase 8 . J Biol Chem 278: 45406-45413, 2003.

42. Schmitz ML, Bacher S and Kracht M: I kappa B-independent control of NF-kappa B activity by modulatory phosphorylations. Trends Biochem Sci 26: 186-190, 2001.
43. Shin Y, Yoon SH, Choe EY, et al: PMA-induced up-regulation of MMP-9 is regulated by a PKCalpha-NF-kappaB cascade in human lung epithelial cells. Exp Mol Med 39: 97-105, 2007.

44. Nguyen J, Gogusev J, Knapnougel P and Bauvois B: Protein tyrosine kinase and p38 MAP kinase pathways are involved in stimulation of matrix metalloproteinase- 9 by TNF-alpha in human monocytes. Immunol Lett 106: 34-41, 2006.

45. Lu Y and Wahl LM: Production of matrix metalloproteinase-9 by activated human monocytes involves a phosphatidylinositol3 kinase/Akt/IKKalpha/NF-kappaB pathway. J Leukoc Biol 78: 259-265, 2005.

46. Simon C, Goepfert H and Boyd D: Inhibition of the p38 mitogen-activated protein kinase by SB 203580 blocks PMAinduced $\mathrm{Mr}$ 92,000 type IV collagenase secretion and in vitro invasion. Cancer Res 58: 1135-1139, 1998.

47. Kozawa O, Kawamura H, Matsuno H and Uematsu T: p38 MAP kinase is involved in the signalling of sphingosine in osteoblasts: sphingosine inhibits prostaglandin F(2alpha)induced phosphoinositide hydrolysis. Cell Signal 12: 447-450, 2000.

48. Hah N and Lee ST: An absolute role of the PKC-dependent NFkappaB activation for induction of MMP-9 in hepatocellular carcinoma cells. Biochem Biophys Res Commun 305: 428-433, 2003.

49. Ellerbroek SM, Halbleib JM, Benavidez M, et al: Phosphatidylinositol 3-kinase activity in epidermal growth factor-stimulated matrix metalloproteinase- 9 production and cell surface association. Cancer Res 61: 1855-1861,2001.

50. Ruhul Amin AR, Senga T, Oo ML, Thant AA and Hamaguchi M: Secretion of matrix metalloproteinase- 9 by the proinflammatory cytokine, IL-1beta: a role for the dual signalling pathways, Akt and Erk. Genes Cells 8: 515-523, 2003.

51. Reddy KB, Krueger JS, Kondapaka SB and Diglio CA Mitogen-activated protein kinase (MAPK) regulates the expression of progelatinase B (MMP-9) in breast epithelial cells. Int J Cancer 82: 268-273, 1999.

52. Esteve PO, Robledo O, Potworowski EF and St-Pierre Y: Induced expression of MMP-9 in C6 glioma cells is inhibited by PDGF via a PI 3-kinase-dependent pathway. Biochem Biophys Res Commun 296: 864-869, 2002.

53. Thant AA, Nawa A, Kikkawa F, et al: Fibronectin activates matrix metalloproteinase-9 secretion via the MEK1-MAPK and the PI3K-Akt pathways in ovarian cancer cells. Clin Exp Metastasis 18: 423-428, 2000.

54. Liu JF, Crepin M, Liu JM, Barritault D and Ledoux D: FGF-2 and TPA induce matrix metalloproteinase-9 secretion in MCF-7 cells through PKC activation of the Ras/ERK pathway. Biochem Biophys Res Commun 293: 1174-1182, 2002.

55. Yao J, Xiong S, Klos K, et al: Multiple signaling pathways involved in activation of matrix metalloproteinase-9 (MMP-9) by heregulin-beta1 in human breast cancer cells. Oncogene 20: 8066-8074, 2001.

56. Kim MH, Albertsson P, Xue Y, Kitson RP, Nannmark U and Goldfarb RH: Expression of matrix metalloproteinases and their inhibitors by rat NK cells: inhibition of their expression by genistein. In Vivo 14: 557-564, 2000.

57. Chakraborti S, Mandal M, Das S, Mandal A and Chakraborti T: Regulation of matrix metalloproteinases: an overview. Mol Cell Biochem 253: 269-285, 2003

58. Nagase H and Woessner JF Jr: Matrix metalloproteinases. J Biol Chem 274: 21491-21494, 1999.

59. Chang C and Werb Z: The many faces of metalloproteases: cell growth, invasion, angiogenesis and metastasis. Trends Cell Biol 11: S37-S43, 2001.

60. McCawley LJ and Matrisian LM: Matrix metalloproteinases: they're not just for matrix anymore! Curr Opin Cell Biol 13: 534-540, 2001. 